\title{
KEBERTAHANAN MASYARAKAT PADA PERMUKIMAN KUMUH BERDASARKAN ASPEK SOSIAL EKONOMI DI KELURAHAN SALATIGA, KOTA SALATIGA
}

\author{
Muhamad Ilham Satrio', Annisa Mu'awanah Sukmawati ${ }^{1}$ \\ ${ }^{1}$ Program Studi Perencanaan Wilayah dan Kota, Fakultas Sains dan Teknologi, Universitas Teknologi Yogyakarta
}

\begin{abstract}
Abstrak
Permukiman kumuh merupakan lingkungan hunian yang kurang layak huni. Permukiman kumuh memiliki karakteristik, seperti kepadatan bangunannya yang tinggi, luasan wilayah permukiman yang terbatas, rawan terjadi penyakit sosial dan penyakit lingkungan, kualitas bangunan yang rendah, dan kurang terlayani sarana dan prasarana yang memadai. Penelitian berlokasi di RW 7 Turusan, Kelurahan Salatiga, Kota Salatiga. RW 7 Turusan termasuk salah satu kawasan permukiman kumuh di Kota Salatiga akibat keragaman aktivitas masyarakat yang menimbulkan berbagai permasalahan, mencakup sosial, ekonomi, dan lingkungan. Meskipun dihadapkan pada permasalahan kumuh, namun masyarakat masih bertahan untuk tetap tinggal di kawasan tersebut. Penelitian bertujuan untuk mengidentifikasi faktor-faktor yang mempengaruhi kebertahanan masyarakat pada permukiman kumuh di RW 7 Turusan Kelurahan Salatiga, Kota Salatiga ditinjau dari aspek sosial ekonomi masyarakatnya. Penelitian menggunakan metode penelitian kualitatif dengan teknik analisis deskriptif kualitatif. Pengumpulan data dilakukan dengan wawancara kepada tujuh responden, observasi lapangan, dan telaah dokumen/ literatur terkait. Penelitian menunjukkan bahwa penyebab kumuh di RW 7 Turusan adalah akibat kondisi fisik/topografi lingkungan serta perilaku masyarakat yang kurang sehat. Meskipun dihadapkan pada persoalan kumuh, beberapa hal yang menyebabkan masyarakat bertahan tinggal di sana adalah karena faktor kedekatan jarak dengan pusat kota terkait mata pencaharian mereka, lama tinggal, ikatan sosial yang erat, dan nilai keguyuban di masyarakat. Namun demikian, faktor ikatan sosial adalah faktor yang paling berpengaruh bagi kebertahanan masyarakat di permukiman kumuh karena mendorong terciptanya inisiasi program lokal untuk peningkatan kualitas lingkungan tempat tinggal.
\end{abstract}

Kata kunci : kebertahanan; Kota Salatiga; permukiman kumuh; RW 7 Turusan

\begin{abstract}
Slum is residential environment that is less livable. Slum has characteristics, among others high density, limited area of residential, susceptibility to social and environmental diseases, low buildings quality, and fewer basic urban services and infrastructure. The research is located at RW 7 Turusan, Kelurahan Salatiga, Salatiga City. RW 7 Turusan is one of the slum areas in Salatiga City due to variaty of activities that causes social, economic, and environmental issues. Nevertheless, the inhabitants still survive living there.. This study aims to identify the factors affecting community's survival in the slum areas of RW 7 Turusan, Kelurahan Salatiga, Salatiga City in terms of community's socio-economic aspects. The research utilizes qualitative research method with qualitative descriptive analysis techniques. Data collection was carried out by interviewing seven respondents conducting field observations, and doing study documents/literature. The research revealed that the emergence of slum areas at RW 7 Turusan is due to the physical condition/ topography and the unhealthy behavior of the inhabitants. Even though they are faced with slum problems, several factors affect inhabitants to remain staying in the area, those are proximity to the city center for livelihoods, length of stay, close social ties, and the social value within community that creates social bonding. Among those factors, the social bonding is the most influential factor for the resilience of communities in the slum settlements since it encourages the creation of local program initiatives to improve the quality of their living environment.
\end{abstract}

Keywords : resilience; RW 7 Turusan; Salatiga City, slum settlements

\section{PENDAHULUAN}

Permukiman kumuh di perkotaan dapat muncul karena pesatnya urbanisasi yang memicu pertambahan penduduk dan kebutuhan hunian. Keterbatasan kemampuan penduduk dalam mengakses permukiman formal mendorong kemunculan 
permukiman informal yang dapat berkembang menjadi permukiman kumuh. Seperti temuan Chimankar (2016) dalam studinya mengenai permukiman kumuh di India bahwa urbanisasi sejalan dengan kemunculan permukiman kumuh apabila pemerintah tidak mampu mengatur urbanisasi yang terjadi. Data BPS Indonesia (2018) menunjukkan terdapat 7,42\% rumah tangga kumuh tinggal di perkotaan. Sementara itu pada skala global, UN-Habitat (2003) menyebutkan bahwa 78,2\% populasi dunia tinggal di kawasan kumuh, terutama populasi pada negara-negara berkembang. Kondisi ini menunjukkan bahwa permukiman kumuh masih melanda berbagai negara di dunia.

Menurut Peraturan Menteri Pekerjaan Umum dan Perumahan Rakyat Republik Indonesia Nomor 02/PRT/M2016 tentang Peningkatan Kualitas terhadap Perumahan Kumuh dan Permukiman Kumuh, permukiman kumuh diartikan sebagai pemukiman yang tidak layak huni karena ketidakteraturan bangunan dan tingkat kepadatan bangunan yang tinggi. UN-Habitat (2003) juga menyebutkan bahwa permukiman kumuh dicirikan dengan lingkungan yang terdegradasi, bangunan tidak layak huni dan berkepadatan tinggi, kurang terlayani infrastruktur dasar terutama sanitasi dan air bersih, kemiskinan, dan eksklusi sosial. Lebih lanjut, Mahabir et al. (2016) menyatakan bahwa permukiman kumuh lebih banyak ditemukan pada negara berkembang atau kurang berkembang sejalan dengan tingginya pertumbuhan populasi serta kemiskinan. Permukiman kumuh pada beberapa negara berkembang lain juga memiliki kondisi yang serupa dengan Indonesia, seperti Chimankar (2016) di India, Uddin (2018) di Bangladesh, dan Danso-wiredu \& Midheme (2017) di Ghana yang mencirikan permukiman kumuh dengan kurangnya infrastruktur, seperti sanitasi, air bersih, layanan kesehatan, serta isu kepemilikan lahan

Permukiman kumuh dapat muncul disebabkan oleh banyak faktor. Penelitian Krisandriyana et al. (2019) mengungkapkan bahwa permukiman kumuh dapat muncul disebabkan faktor tata ruang, ekonomi, dan status lahan. Serupa dengan Surtiani (2006) yang menyatakan bahwa kondisi tingkat penghasilan, status kepemilikan hunian, dan lama tinggal mempengaruhi kondisi kekumuhan suatu kawasan. Ini menunjukkan bahwa kemunculan kawasan permukiman kumuh berlangsung dalam kurun waktu tertentu, dilatarbelakangi oleh kondisi ekonomi yang sebagian besar dihuni oleh penduduk ekonomi menengah ke bawah, serta ada pengaruh dari status kepemilikan lahan/hunian yang rata-rata berstatus sewa sehingga rendahnya rasa kepemilikan.

Meskipun permukiman kumuh kerap memiliki stigma negatif, permukiman kumuh juga perlu dipandang secara positif. Sebagaimana diungkapkan oleh UN-Habitat (2003) bahwa permukiman kumuh membantu pada imigran yang baru pindah ke kota untuk memulai kehidupan di kota. Selain itu, permukiman kumuh menjadi tempat bagi sektor informal untuk tumbuh dan mampu menghidupkan kota. Permukiman kumuh juga menjadi wadah bagi penghuninya untuk mengakulturasikan budaya antara penghuni lama dengan kaum pendatang. Sejalan dengan Owusu et al. (2008) dalam studinya di Ghana bahwa keberadaan migran pada permukiman kumuh berperan dalam membentuk citra kumuh suatu kawasan dan hendaknya tidak selalu dipandang secara negatif. Untuk mengubah citra tersebut perlu ada upaya perbaikan kualitas lingkungan dan sosial budaya berbasis masyarakat.

Adanya dualisme kondisi positif dan negatif dari permukiman kumuh tersebut menjadikan masih ada penduduk yang bertahan dan tetap tinggal. Meskipun dihadapkan pada permasalahan lingkungan tempat tinggal, namun faktor sosial budaya yang telah terinternalisasi mendorong penduduk untuk bertahan. Permukiman kumuh memiliki peran tersendiri bagi penghuninya untuk meningkatkan kualitas hidupnya meskipun dihadapkan pada masalah keindahan kota (Indriani, 2017). Seperti temuan Dewi \& Syahbana (2015) dan Evansyah \& Dewi (2014) bahwa adanya ikatan sosial/kekerabatan yang erat serta aktivitas budaya mempengaruhi kebertahanan penduduk pada permukiman informal. Beberapa temuan lain juga menunjukkan bahwa kebertahanan masyarakat pada permukiman kumuh terbentuk karena adanya hubungan turun menurun yang menyebabkan jarangnya pendatang baru (Susanti, Harani, \& Hasan, 2018). Pada konteks global, penelitian Andavarapu \& Arefi (2016) pada permukiman kumuh di Pedda-Jalaripeta, India menjelaskan bahwa untuk dapat mencapai kebertahanan (resilience) masyarakat perlu bertransformasi dan beradaptasi dalam kurun waktu yang cukup lama. Selain itu, adanya modal sosial untuk bertahan dari bencana serta kolaborasi masyarakat dengan pemerintah dan bukan pemerintah membantu masyarakat untuk segera pulih dari tekanan bencana/konteks kekumuhan yang terjadi. Untuk membangun masyarakat yang dapat bertahan, diperlukan upaya pemberdayaan masyarakat jangka panjang terkait dengan partisipasi masyarakat. Selain itu, juga diperlukan kolaborasi berbagai pihak baik lokal maupun dari luar (Ahmed, 2016).

Penelitian berlokasi di Kelurahan Salatiga, Kota Salatiga. Secara administratif Kota Salatiga memiliki 4 kecamatan dan 23 kelurahan, yaitu Kecamatan Argomulyo, Kecamatan Tingkir, Kecamatan Sidomukti, dan Kecamatan Sidorejo. Kelurahan 
Salatiga berada di wilayah administrasi Kecamatan Sidorejo. Kelurahan Salatiga memiliki luas wilayah $202 \mathrm{Ha}$ dan dihuni oleh 14.656 penduduk pada tahun 2019. Kedudukan Kelurahan Salatiga terhadap Kota Salatiga terlihat di Gambar 1.

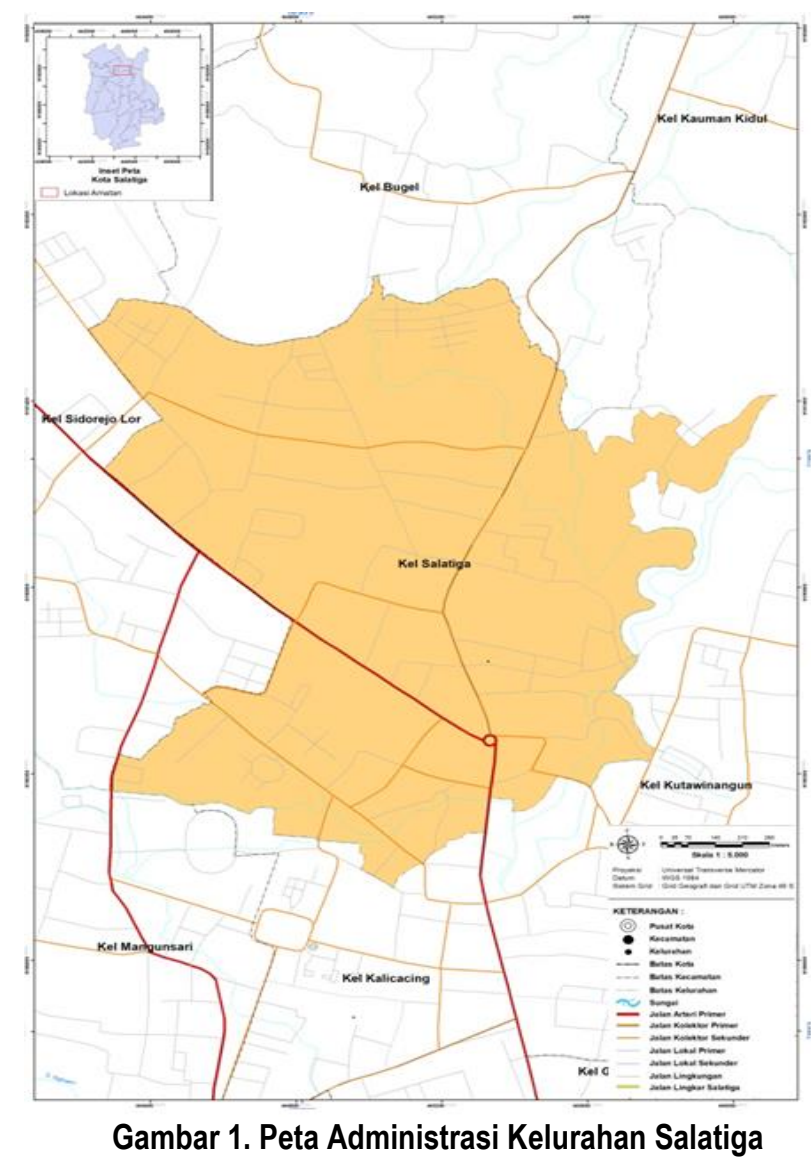

Kelurahan Salatiga terletak di pusat Kota Salatiga dan memiliki kepadatan penduduk yang relatif tinggi, yaitu 73 jiwa/Ha. Menurut Surat Keputusan Walikota Salatiga Nomor 658/440/2016 tentang lokasi program Kota Tanpa Kumuh (KOTAKU) di Kota Salatiga, Kelurahan Salatiga ditetapkan sebagai salah satu kelurahan kumuh di Kota Salatiga dengan tingkat kekumuhan rendah dan mendapat program prioritas penanganan kumuh. Beberapa RW yang mendapat program penanganan permukiman kumuh di Kelurahan Salatiga berada di RW 4, RW 5, dan RW 7. Kondisi kumuh di Kelurahan Salatiga disebabkan oleh tingkat pendapatan masyarakat yang rendah, rendahnya kesadaran masyarakat untuk menjaga kebersihan lingkungan, dan sebagian besar penduduk $(56,24 \%)$ masih memiliki tingkat pendidikan rendah yang hanya tamatan SD, SMP, dan SMA. Program-program yang direncanakan untuk perbaikan kondisi kumuh di Kelurahan Salatiga meliputi program peningkatan kualitas permukiman kumuh serta pencegahan tumbuh dan berkembangnya permukiman kumuh.

Fokus studi berada di RW 7 Turusan karena menurut data yang ada RW 7 merupakan daerah permukiman kumuh terbaru. Selain itu, didukung pula dengan luasan wilayah kumuhnya yang cukup besar dibandingkan dengan RW yang lain. Alasan lainnya adalah belum adanya penelitian mengenai permukiman kumuh yang mengambil lokasi studi di RW 7 Turusan.

Permukiman kumuh di Kelurahan Salatiga berkembang secara signifikan dan menciptakan berbagai permasalahan yang kompleks sehingga perlu ada penelitian yang terkait langsung dengan permukiman kumuh. Adanya keberadaan permukiman kumuh di Kelurahan Salatiga, Kota Salatiga menyebabkan aktivitas di dalamnya menjadi beragam, sehingga menimbulkan berbagai permasalahan, baik aspek sosial, ekonomi, dan lingkungan. Meskipun dihadapkan pada berbagai permasalahan, namun masyarakat masih tetap mau bertahan bertempat tinggal di lingkungan yang terkategori sebagai permukiman kumuh. Selain karena karakteristik permukiman kumuh, ada beberapa alasan yang menjadikan masyarakat setempat yang masih mau untuk bertempat tinggal yang menarik untuk digali terkait dengan perilaku masyarakatnya. Untuk itu, muncul pertanyaan penelitian "Apa saja faktor yang mempengaruhi kebertahanan masyarakat pada permukiman kumuh di RW 7 Turusan 
Kelurahan Salatiga, Kota Salatiga jika dilihat dari aspek sosial ekonomi masyarakatnya?" Sementara itu, penelitian bertujuan untuk mengidentifikasi faktor-faktor yang mempengaruhi kebertahanan masyarakat pada permukiman kumuh di RW 7 Turusan Kelurahan Salatiga, Kota Salatiga ditinjau dari aspek sosial ekonomi masyarakat.

\section{KAJIAN PUSTAKA}

\subsection{KARAKTERISTIK PERMUKIMAN KUMUH}

Undang-Undang Republik Indonesia Nomor 1 Tahun 2011 tentang Perumahan dan Kawasan Permukiman mendefinisikan permukiman kumuh sebagai permukiman yang tidak layak huni karena ketidakteraturan bangunan, tingkat kepadatan bangunan yang tinggi, dan kualitas bangunan serta sarana dan prasarana yang tidak memenuhi syarat. Banyak studi juga telah menunjukkan karakteristik permukiman kumuh. Seperti hasil penelitian Nursyahbani \& Pigawati (2015) yang mencirikan permukiman kumuh sebagai permukiman dengan kualitas bangunan rendah dan tidak layak huni, kepadatan bangunan tinggi dan kurang ruang terbuka, legalitas kepemilikan lahan tidak terjamin, didominasi oleh penduduk pendatang, kurang terlayani sarana air bersih dan air limbah, dan dihuni oleh penduduk berpenghasilan sangat rendah. Lebih lanjut, Krisandriyana et al. (2019) menjelaskan bahwa faktor penentu karakteristik permukiman kumuh dapat saja berbeda, disesuaikan dengan tipologi dari kawasan kumuh itu sendiri, seperti kawasan permukiman kumuh di bantaran sungai, permukiman kumuh di sepanjang rel kereta api, dan permukiman kumuh padat perkotaan. Dari beberapa definisi tersebut dapat dirumuskan bahwa permukiman kumuh adalah permukiman yang lingkungan hunian kualitasnya tidak layak untuk dihuni dan memiliki ciri-ciri, seperti kepadatan bangunan yang sangat tinggi dalam luasan wilayahnya yang sangat terbatas, rawan terjadinya penyakit sosial dan penyakit lingkungan, kualitas bangunannya yang sangat rendah, dan kurang terlayaninya sarana dan prasarana yang memadai.

UN-Habitat (2007) mendefinisikan rumah tangga dalam permukiman kumuh (slum households) sebagai kelompok individu yang tinggal di bawah satu atap di daerah perkotaan yang tidak mempunyai salah satu dari indikator: a) Rumah kokoh yang dapat melindungi penghuninya dari kondisi cuaca yang buruk, b) Rumah huni yang cukup, dimana tidak lebih dari tiga orang menghuni satu ruang bersama, dan c) Kepastian atau rasa aman bermukim (secure tenure) yang dapat melindungi penghuni dari penggusuran paksa. Lebih lanjut, UN-Habitat \& UNESCAP (2008) menjelaskan kriteria permukiman kumuh sebagai rumah tangga yang memiliki salah satu dari kriteria berikut: a) Tidak memadainya ketersediaan air minum yang aman (inadequate access to safe water), b) Tidak memadainya ketersediaan sanitasi beserta infrastrukturnya (inadequate access to sanitation and other infrastructure), c) Kualitas bangunan yang rendah (poor structural of housing), d) Ruang huni yang padat (overcrowding), dan e) Status hunian yang tidak aman (insecure residental status).

\subsection{KEBERTAHANAN MASYARAKAT PADA PERMUKIMAN KUMUH}

Kebertahanan berasal dari kata dasar "bertahan" yang diartikan sebagai mempertahankan diri (terhadap serangan, godaan, dan sebagainya) (KBBI Daring, 2016). Lebih jelasnya Juwono (2009) membedakan pengertian ketahanan dan kebertahanan, dimana "ketahanan merupakan sesuatu yang telah diketahui kekuatan atau kemampuannya. Sedangkan kebertahanan merupakan masih terbatas pada fenomena yang belum diketahui kekuatan atau kemampuannya". Selain itu, penggunaan kata kebertahanan juga banyak digunakan pada konteks permukiman untuk menunjukkan fenomena bertahan suatu permukiman serta terkait dengan kemampuan masyarakat untuk bertahan untuk tetap tinggal di suatu lingkungan permukiman yang berada dalam kondisi kurang baik, seperti kumuh, terdegradasi, atau mengalami tekanan akibat perkembangan kota.

Adanya keinginan masyarakat untuk tetap tinggal perlu dibarengi oleh adanya langkah adaptasi. Magis (2010) menjelaskan bahwa kebertahanan masyarakat sebagai keberadaan, pengembangan, dan keterlibatan sumber daya masyarakat untuk berkembang di lingkungannya yang dicirikan oleh perubahan. Hal ini menunjukkan bahwa dalam konsep kebertahanan terhadap proses belajar atau evolusi di berbagai aspek kehidupan, baik sistem sosial masyarakat dan pemerintah untuk dapat bertahan terhadap perubahan. Reivich dan Shatte (2002) menjelaskan bahwa kebertahanan adalah kemampuan untuk merespon suatu rintangan, hambatan, maupun tekanan dengan sehat dan produktif. Walker et al (2010) merumuskan bahwa kebertahanan (resilience) dapat didefinisikan sebagai kemampuan. Kawasan yang selama ini menjadi kumuh pada umumnya merupakan kawasan yang biasanya memiliki tingkat kerentanan terhadap bencana yang cukup tinggi. 
Beberapa penelitian menunjukkan mengenai konsep kebertahanan pada permukiman, khususnya pada permukiman informal. Jones (2017) dalam kasusnya pada permukiman di informal city menunjukkan bahwa untuk dapat bertahan dalam kampung, masyarakat perlu beradaptasi dengan memodifikasi fungsi ruang sebagai ruang multifungsi dan menerapkan pendekatan fleksibelitas dan responsif dalam merespon segala perubahan yang terjadi pada ruang kampung. Dewi \& Syahbana (2015) pada kasusnya di Kampung Pedamaran, Kota Semarang menemukan bahwa kampung dapat bertahan dari berbagai permasalahan terutama terhadap banjir dan kemiskinan karena adanya ikatan sosial antar penduduk kampung yang baik serta kemudahan mencari nafkah. Ikatan sosial tersebut berupa hubungan kekerabatan antar penduduk dan dapat menciptakan keamanan lingkungan karena adanya rasa saling memiliki. Penelitian Evansyah \& Dewi (2014) di Kampung Sekayu, Kota Semarang juga menjelaskan bahwa mayoritas penghuni kampung adalah penduduk pendatang. Namun, adanya ikatan sosial, aktivitas budaya yang masih dilestarikan, dan kedekatan serta kemudahan ekonomi menjadikan masyarakat masih memilih bertahan meskipun kampung terancam akibat pembangunan kota.

Penelitian Susanti et al. (2019) di Kampung Malang, Kota Semarang juga menunjukkan bahwa adanya kemudahan ekonomi karena lokasi kampung yang berada pada kawasan perdagangan yang ramai, nilai kesejarahan kampung, serta dominasi penduduk oleh warga asli dan telah menghuni kampung secara turun temurun menjadikan warga tetap bertahan di kampung tersebut meskipun lokasinya dikelilingi bangunan komersial. Adanya batas ruang yang jelas antara bangunan komersial dan rumah warga di Kampung Malang menjadikan seolah-olah bangunan komersial tersebut menjadi benteng dari kampung tersebut. Hasil penelitian Shirleyana \& Sunindijo (2018) pada kasusnya di Surabaya menjelaskan bahwa ikatan sosial merupakan hal penting untuk memfasilitasi strategi adaptasi masyarakat kampung. Selain itu, diperlukan juga aspek pendukung lain, seperti partisipasi masyarakat, keterikatan tempat, identitas tempat, keamanan dan stabilitas ekonomi, dan dukungan pemerintah. Sejalan dengan temuan Aprianto (2016) di Kampung Petempen, Kota Semarang bahwa kenyamanan tinggal, faktor ekonomi, serta telah adanya langkah adaptasi terhadap kondisi tempat tinggal menyebabkan masyarakat enggan pindah.

Berdasarkan beberapa literatur tersebut, maka kebertahanan masyarakat dalam permukiman kumuh dapat muncul oleh adanya ikatan sosial, adaptasi lingkungan, inisiatif pengembangan dari kelompok atau komunitas, identitas tempat, perlindungan terhadap lingkungan, dan adanya dukungan dari beberapa pihak. Beberapa penelitian juga telah membuktikan bahwa modal sosial berperan penting bagi kebertahanan masyarakat untuk tetap tinggal di permukiman kumuh (Andavarapu \& Arefi, 2015, 2016; Tauhid, 2019). Andavarapu \& Arefi $(2015,2016)$ pada kasusnya di India menemukan konsep adaptive cycle framework sebagai bentuk kebertahanan masyarakat pada permukiman kumuh di perkotaan yang berbasis pada modal sosial serta kolaborasi dengan berbagai pihak. Konsep ini terdiri dari empat tahapan, yaitu conservation, creative destruction, reorganization, dan exploitation. Serupa dengan Ahmed (2016) dalam studinya di Bangladesh bahwa untuk membangun kebertahanan masyarakat pada permukiman kumuh diperlukan suatu pilot project atau aktivitas yang bersifat jangka panjang yang menuntut adanya peningkatan kapasitas dan kerjasama berbagai pihak, serta dukungan kebijakan/politik yang berpihak. Untuk itu, dapat dijelaskan bahwa beberapa faktor yang mempengaruhi kebertahanan masyarakat adalah karena adanya hubungan yang terjalin dalam masyarakat, keterbukaan dalam komunikasi, hubungan yang sudah terbentuk sebelumnya, teknologi, struktur masyarakat, dan penyediaan sarana dan prasarana.

\section{METODE PENELITIAN}

Penelitian dilakukan dengan menggunakan metode penelitian kualitatif. Creswell (2014) mengartikan metode penelitian kualitatif sebagai penelitian yang bersifat deskriptif karena sifatnya untuk menggali informasi secara mendalam. Metode penelitian kualitatif dipilih karena peneliti ingin menemukenali fenomena permukiman kumuh yang terjadi di RW 7 Turusan, Kelurahan Salatiga, Kota Salatiga dan merumuskan faktor yang menyebabkan masyarakat tetap bertahan tinggal pada permukiman kumuh.

Teknik analisis data yang digunakan adalah teknik analisis deskriptif kualitatif. Teknik analisis data deskriptif kualitatif yang dilakukan dengan cara mengumpulkan berbagai informasi data dan digunakan dengan tujuan untuk mengetahui karakteristik data-data yang dikumpulkan menjadi satu yang berasal dari berbagai sumber penelitian yang dilakukan. Menurut Miles \& Huberman (1994) ada tiga tahapan analisis kualitatif, yaitu reduksi data, penyajian data, dan verifikasi data. Pertama, tahap reduksi data merupakan proses pemilihan, pemusatan perhatian pada penyederhanaan, pengabstrakan, transformasi data kasar yang muncul dari catatan-catatan di lapangan. Reduksi data yang diterapkan pada Kelurahan Salatiga adalah dengan 
menggunakan proses pemilihan maupun penyederhanaan data yang muncul dari catatan tertulis di lapangan dan dikategorikan beberapa tema penelitian sehingga muncul beberapa uraian yang dapat ditarik garis kesimpulan. Reduksi data diawali dengan membuat transkripsi wawancara yang dilanjutkan dengan pengkodingan dan pembuatan beberapa tema penelitian untuk dapat melihat pola-pola temuan hasil wawancara yang didapatkan. Pengkodingan dilakukan dengan menggunakan kode sebagai berikut (Inisial informan, tahap wawancara ke-, tanggal wawancara, baris kutipan wawancara pada transkrip wawancara). Kedua, tahap penyajian data dilakukan dengan menulis narasi atau jalan cerita penelitian yang disertai pula dengan tabel, gambar, grafik. Penyajian secara naratif dilakukan untuk menjelaskan tiga sasaran, yaitu karakteristik masyarakat berdasarkan kondisi sosial ekonomi dan karakteristik permukiman kumuh di RW 7 Turusan. Ketiga, tahap penarikan kesimpulan/verifikasi dilakukan dengan teknik triangulasi, yaitu menggunakan berbagai sumber data dan berbagai metode pengumpulan data untuk mendeskripsikan fenomena yang ada sebagai bentuk dari pengecekan kepercayaan data dapat dilakukan. Verifikasi data dilakukan dengan menyebutkan minimal tiga informan untuk suatu pernyataan yang bermakna sama atau sejenis. Secara lebih jelas, bagan analisis penelitian tersaji di Gambar 2.

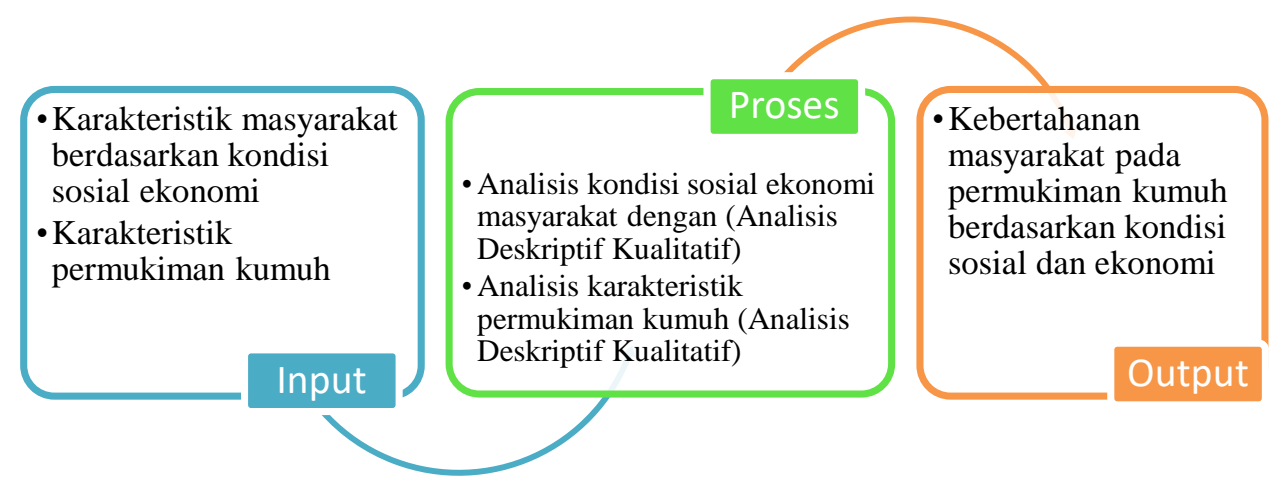

Gambar 2. Bagan Analisis Penelitian

Metode pengumpulan data dilakukan dengan metode pengumpulan data primer dan sekunder. Data primer adalah data yang langsung diperoleh dari sumber data (lapangan) secara langsung dengan teknik observasi dan wawancara terkait penelitian permukiman kumuh ini. Teknik observasi digunakan untuk mengamati karakteristik kumuh yang terdapat di RW 7 Turusan, Kelurahan Salatiga. Sedangkan teknik wawancara adalah teknik pengumpulan data yang bersumber langsung dari sumber data dengan menggunakan teknik wawancara untuk menggali informasi mengenai karakteristik permukiman kumuh di Kelurahan Salatiga, program penanganan permukiman kumuh di Kelurahan Salatiga, dan karakteristik sosial dan ekonomi masyarakat. Wawancara dilakukan dengan wawancara mendalam (in-depth interview) dengan teknik purposive sampling dan snowball sampling kepada tujuh informan, yaitu Dinas Perumahan dan Permukiman Kota Salatiga, Bappeda Kota Salatiga, Pemerintah Kelurahan Salatiga, ketua RT/RW, dan tokoh masyarakat.

Pengumpulan data sekunder adalah sumber data yang berasal dari berbagai instansi yang terkait langsung, seperti Badan Perencanaan Pembangunan Daerah (Bappeda) Kota Salatiga, Dinas Perumahan dan Permukiman Kota Salatiga, dan Kantor Kelurahan Salatiga, Kota Salatiga. Selain dari adanya telaah dokumen dari beberapa instansi di Kota Salatiga, data sekunder juga bisa didapatkan dari beberapa macam pengolahan studi literatur yang terkait langsung dan berkesinambungan dengan penelitian yang dilakukan.

Instrumen penelitian yang digunakan oleh peneliti meliputi buku catatan kecil sebagai alat menulis catatan kaki bila diperlukan sewaktu-waktu, alat perekam suara, kamera handphone, berbagai keperluan alat tulis, peta wilayah administrasi Kelurahan Salatiga maupun beberapa peta lain sebagai bahan pendukung, dan tabel kebutuhan data yang diperlukan. Tujuan adanya instrumen penelitian adalah agar data yang diperoleh benar adanya dengan kondisi di lapangan. 


\section{HASIL DAN PEMBAHASAN}

\subsection{KARAKTERISTIK PERMUKIMAN KUMUH DI RW 7 TURUSAN, KELURAHAN SALATIGA}

Kondisi fisik permukiman kumuh di Kelurahan Salatiga tampak dari kondisi bangunan yang rapat dengan kualitas konstruksi rendah. Kondisi kekumuhan yang terjadi karena karakteristik masyarakatnya dengan ciri-ciri jumlah penduduk padat, kurang sadarnya akan kondisi lingkungan yang bersih, dan penghasilan yang rendah. Di sisi lain, masyarakat masih kurang mendapatkan fasilitas yang maksimal, baik infrastruktur fisik dan sosial. Jarak antar bangunan yang rapat kurang memungkinkan untuk dibangunnya fasilitas dasar yang memadai, seperti sanitasi.

“.....kesadaran masyarakat istilahnya kurang peduli dengan lingkungan sendiri....” (SKA W2 11022020, 58-59).

"Permukiman kumuh ya permukiman yang terlalu dekat antar rumahnya terus disitu tidak ada sarana-sarana untuk digunakan semisalkan untuk mandi, cuci kakus tidak ada" (ASY W6 04032020, 20-24).

Hal lain yang menyebabkan kekumuhan di RW 7 Turusan adalah karena lokasinya geografisnya yang rendah dan berdekatan dengan aliran Sungai Kedawun. RW 7 Turusan menjadi daerah paling rendah karena kenampakan fisiknya berupa turunan yang berasal dari arah Kota Salatiga dan menjadikannya aliran yang berasal dari hulu ke hilir. Sehingga pola turunnya aliran air buangan langsung turun ke RW 7 baik buangan yang berupa cucian masyarakat, limpahan air hujan, maupun air limbah masyarakat.

"Nggeh mergone teng mriki niku kondisi geografisnya niku paling rendah....." (MMI W5 12022020, 3-4)

“....pembuangan air hujan dari atas kesini semua.....” (SGY W4 18022020, 55-56)

“.....ya itu lokasinya deket sungai-sungai itu, iya itu daerah Kalisumbo Kalitaman itu kan mata air...." (DSR W7 05032020, 84-86)

Selain kondisi topografi yang berada di daerah hilir, keberadaan RW 7 Turusan yang dekat dengan aliran sungai menjadikannya kerap menerima limpahan sampah dari sepanjang aliran sungai, seperti sampah plastik, sampah elektronik, sampah kasur, dan sampah-sampah lainnya. Tidak hanya dari limpahan, akan tetapi ada juga beberapa oknum masyarakat yang melakukan aksi buang sampahnya sembarangan. Oknum masyarakat yang membuang sampah di sungai ini beranggapan bahwa membuang sampah langsung di sungai mudah dan cepat untuk diakses daripada membuang pada tempatnya.

"Sampah niku limpahannya dari atas, mesti sampahnya kalo enggak sampah plastik, makanan, kasur, baju, ya itu....." (MMI W5 12022020, 13-15)

"Untuk disini, kaitannya aliran air mengalir bukan hanya sampah warga-warga sini saja tapi juga dapat kiriman dari luar daerah dari atas Krajan ataupun dari Kalitaman...." (HS W1 19022020, 57-60)

".....terkadang mindset masyarakat itu masih ada sebagian yang menganggap kalau buang sampah cukup dikali saja enggak usah ke tempat sampah pokoknya paling deket lah dilempar" (ASY W6 04032020, 89-93)

Selain karena faktor kondisi fisik lingkungan maupun geografis, karakteristik masyarakat yang telah terbentuk sejak lama juga mempengaruhi munculnya image kumuh di RW 7 Turusan. Karakteristik masyarakat terbentuk dari sejak lama maupun terbentuk karena masih belum bisa untuk menerima pembaruan yang ada sehingga menyebabkan terbentuknya kawasan padat penduduk dan berpeluang menjadi kawasan permukiman kumuh. Kondisi lingkungan RW 7 Turusan terlihat di Gambar 3. 


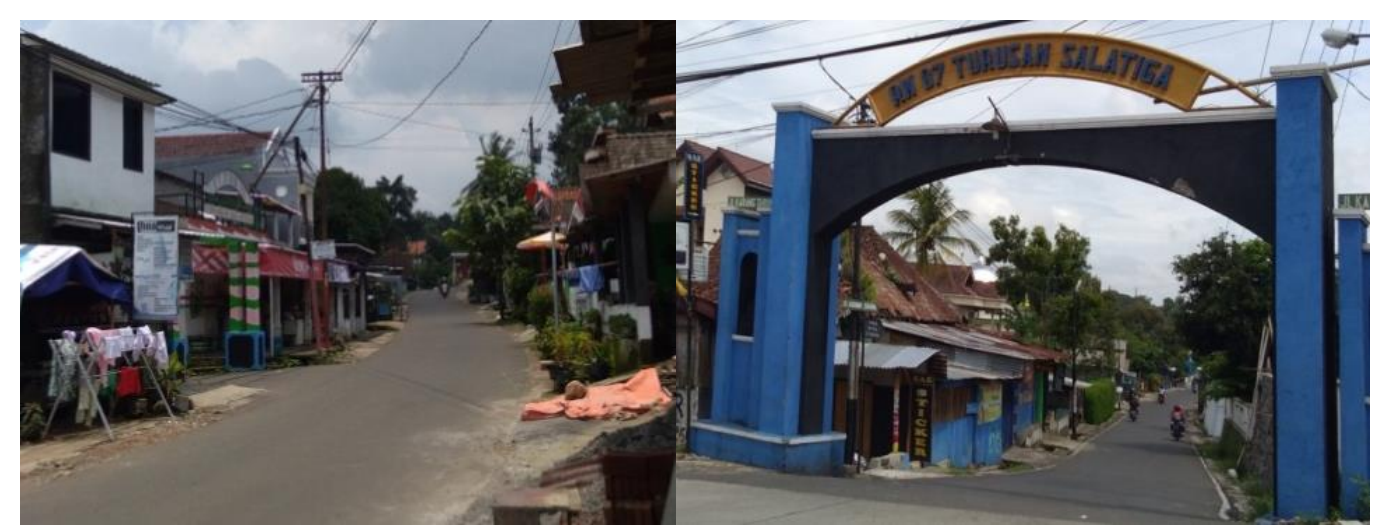

Gambar 3. Kondisi Lingkungan RW 7 Turusan

Buang Air Besar Sembarangan (BABS) yang terjadi di lingkungan RW 7 Turusan adalah suatu fenomena yang menjadi kebiasaan yang masih dilakukan oleh sebagian masyarakat. Ini dikarenakan mindset masyarakat yang beranggapan bahwa buang air besar langsung di sungai lebih leluasa. Kekhasan yang terjadi inilah memunculkan tempat "tongkrongan". "Tongkrongan" di RW 7 Turusan adalah tempat untuk kegiatan mandi, cuci kaskus, dan kegiatan lainnya yang masih sering menggunakan air sungai. Penggunaan "tongkrongan" berlangsung pada tiap pagi, sore dan malam hari. Meskipun menjadi fenomena yang dirasa biasa oleh masyarakat setempat, namun bagi kaum pendatang/pengunjung membuat mata kurang sedap dipandang. Gambar 4 menunjukkan kondisi "tongkrongan" yang kurang layak.

"Ya, buang air besar sembarangan (BABS) nya langsung ke sungai....." (HS W1 19022020, 21-22)

“....nongkrongnya ya BABS itu, itu kan bisa kelihatan mas kalau pagi....” (MMI W5 12022020, 73-74)

".....WC nya kondisinya kurang enak diliat, bagi jarang yang melihat, mungkin bagi orang sekitar sudah terbiasa...." (ARS W8 05032020, 11-13)

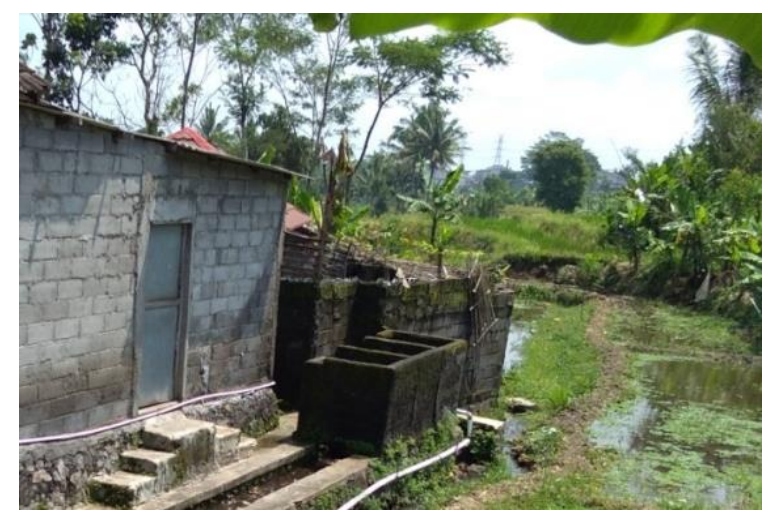

Gambar 4. Kondisi “Tongkrongan” yang Kurang Layak

Meskipun telah menjadi budaya/kebiasan bagi masyarakat setempat, akan tetapi telah ada langkah untuk mengedukasi masyarakat dari pihak RT maupun RW berupa spanduk peringatan. Spanduk peringatan ini bertujuan memberikan pemahaman bagi masyarakat setempat agar tidak melakukan BABS di sepanjang aliran sungai. Selain itu, juga sudah ada upaya/rencana untuk membangun WC komunal yang nyaman bagi masyarakat. Namun, rencana tersebut tidak dapat terealisasikan karena sebagian besar masyarakat merasa keberatan dan memilih untuk membangun WC perorangan di rumah masing-masing.

Masyarakat RW 7 Turusan, bekerjasama dengan pihak kelurahan, juga memiliki program untuk peningkatan kualitas lingkungan, yaitu program RW Sehat. Program RW Sehat berupaya untuk mendorong masyarakat agar dapat secara mandiri mengenali dan menyelesaikan berbagai permasalahan yang ada di lingkungannya dengan kegiatan yang berfokus pada 
lingkungan, seperti bank sampah dan koperasi sampah. Jadi, tujuan dari RW Sehat yang dikembangkan di RW 7 Turusan adalah untuk meningkatkan peran aktif masyarakat sebagai upaya mengurangi citra kumuh dan juga untuk menggalakan gaya hidup sehat di masyarakat. Inisiasi program RW Sehat di RW 7 Turusan sudah berjalan dengan cukup baik. Contoh penerapannya terdapat di lingkungan RT 8 yang memiliki tempat untuk cuci tangan masyarakat di depan rumah masingmasing (Gambar 5).

".....RW Sehat juga, adanya pembinaan dari kelurahan untuk mengantisipasi ataupun mengurangi kekumuhan yang disebabkan pola hidup warga" (HS W1 19022020, 35-38)

"Ya programnya sudah dimiliki istilahe RW Sehat, koperasi sampah, bank sampah....." (SKA W2 11022020, 23-24)

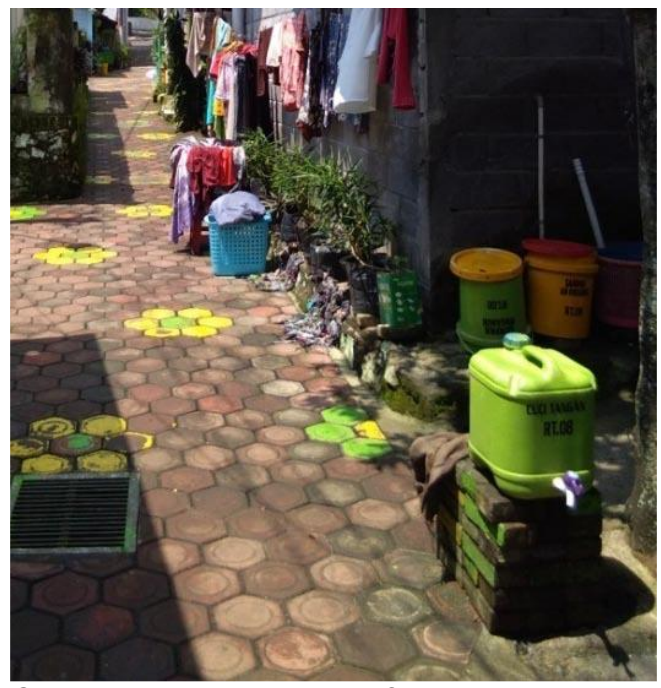

Gambar 5. Kondisi Tempat Cuci Tangan di RT 8

\subsection{KEBERTAHANAN MASYARAKAT DI RW 7 TURUSAN, KELURAHAN SALATIGA}

Kebertahanan adalah kondisi keadaan masyarakat yang dimana mampu dan dapat bertahan terhadap lingkungannya dalam menghadapi permasalahan-permasalahan yang tidak dapat diduga sebelumnya. Reivich \& Shatte (2002) memaknai kebertahanan sebagai kemampuan untuk merespon suatu rintangan, hambatan, maupun tekanan dengan sehat dan produktif. Untuk itu, dapat dikatakan bahwa kebertahanan masyarakat pada permukiman kumuh adalah kemampuan masyarakat untuk tetap tinggal/berada di lingkungan kumuh dengan memperhatikan beberapa faktor-faktor penyebab terjadinya baik yang terjadi secara alami maupun akibat perilaku masyarakat yang menyebabkan kondisi kumuh serta adanya upaya masyarakat untuk beradaptasi dengan kondisi tersebut.

Kelurahan Salatiga yang terletak di jantung Kota Salatiga menjadi representasi wajah kota pada umumnya. Peruntukan fungsi permukiman yang ada di Kelurahan Salatiga relatif cukup lengkap untuk kondisi sarana perekonomiannya. Sarana perekonomian tersebut, seperti pasar, toko, ruko-ruko modern dan pusat perbelanjaan. Geliat permukiman di RW 7 Turusan dari adanya sarana pendidikan berupa sekolah-sekolah mulai dari tingkat dasar, menenggah, hingga atas dan terdapat pula beberapa universitas maupun lembaga setingkat yang menjadi salah satu keuntungan tersendiri bagi masyarakat sekitar khususnya di Kelurahan Salatiga. Keberadaan sarana pendidikan tersebut juga mampu mendongkrak perekonomian masyarakatnya.

Masyarakat RW 7 Turusan menggantungkan kehidupannya dengan bermata pencaharian di sekitar lingkungan tempat tinggalnya. Kedekatan lokasi tempat tinggal dengan pusat kegiatan, baik untuk bekerja, bersekolah, berbelanja, dan lainnya menjadikan warga memilih untuk bertempat tinggal di RW 7 Turusan. Masih banyaknya masyarakat yang bekerja sebagai buruh, pedagang, maupun pekerjaan lainnya yang masih dalam kategori menenggah kebawah. Pengaruh kategorisasi masyarakat berpengahasilan rendah ini karena latar belakang pendidikan masyarakatnya yang masih kebanyakan hanya 
mengenyam hingga sekolah menenggah saja. Kemudian hal inilah yang menimbulkan beberapa permasalahan karena masyarakat yang masih berpenghasilan rendah.

".....sosial ekonominya rata-rata buruh lepas terus buruh cuci, buruh rumah tangga walaupun yang laki-laki tukang kerja di pabrik sosis juga ini mempengaruhi terus latar latar belakang pendidikan yang rata-rata lulusan smp, sma....." (HS W1 19022020, 155-160)

“.....kebanyakan menenggah kebawah ya yang jelas buruh pasti, ya buruh pabrik, buruh orang perorang, buruh accidentil, buruh kebun atau disuruh ngecat dan sebagainya" (SKA W2 11022020, 78-82)

"Kalo sosial ekonominya itu masih kategori menengah kebawah, banyak menengah kebawah....." (SGO W3 17022020, 154-156)

Selain karena faktor ekonomi, banyak dari warga RW 7 yang sudah tinggal secara turun temurun di rumahnya saat ini dan merupakan warga asli. Sebanyak $75 \%$ warga adalah penduduk asli/warga lama dan $25 \%$ adalah penghuni baru yang baru bertempat tinggal sejak tahun 2000 -an. Kondisi ini mendorong warga untuk enggan berpindah tempat tinggal karena status kepemilikan rumahnya yang sudah Hak Milik dan ditinggali turun temurun, meskipun dalam perjalanannya lingkungan tempat tinggal mengalami dinamika dan memunculkan citra kumuh kawasan.

"Sudah lama, dari tahun 72, kebetulan apa ya gak ngerti ya kan dulu begini saya kesini dulu kan, terus kembali lagi, balik lagi, kembali lagi, ya gatau ya kenapa, tapi memang satu ketika saya ada perasaan menjelang pension saya kembali kesini." (SKA W2 11022020, 120-124)

“Saya sudah 30 tahunan...." (MMI W5 12022020, 195)

"Karena ya tanah itu dari dulu....." (SGO W3 17022020, 175)

Dampak yang terjadi akibat masyarakat sudah tinggal secara turun temurun adalah masyarakat memiliki ikatan sosial yang erat. Hal ini dapat terlihat dari masyarakat yang menjunjung nilai kebersamaan (keguyuban) dan kegotong-royongan yang direfleksikan dalam kegiatan sosial yang rutin dilakukan, seperti jimpitan, kerja bakti, dasawisma, pengajian, dan lainnya. Di sisi lain, keeratan hubungan sosial secara informal juga digambarkan dengan kebiasaan jagongan yang sering dilakukan warga meski hanya sekedar menyapa tetangga yang lewat. Adanya hubungan sosial yang erat ini dapat menjadi potensi tersendiri untuk mengurangi dampak kumuh.

“.....ya kalo ada antar tetangga sini itu rukun. Dulu disini kan walaupun sifatnya kelurahannya masuk Salatiga masuk kota, budayanya kan masih budaya pedesaan, gotong royong jadi masih kentel, jagongan, lah dulu kan pernah termasuk mengurangi dari dampak kumuh" (MMI W5 12022020, 120-125)

"......wong sini warga kami kebetulan ya kerja bakti, kita di RT ada tiga dasawisma itu hampir tiga minggu sekali kerja bakti...." (SGO W3 17022020, 176-179)

".....seperti itu mereka guyub ketahanannya karena merasa satu keluarga, jadi semua ngisi” (SGY W4 18022020, 194-196)

“.....kita ada jagongan, kegiatan pengajian-pengajian masing-masing RT sudah mulai diaktifkan....." (HS W1 19022020, 253-255)

Selain itu, adanya inisiasi bersama dari masyarakat untuk mengadakan program penanganan kumuh, seperti bank sampah juga menggambarkan bahwa masyarakat secara bersama-sama ingin mengentaskan permasalahan kumuh di tempat tinggalnya. Program bank sampah mengajarkan masyarakat untuk dapat memilah sampahnya dan mengolahnya menjadi sumber pemasukan pribadi, sehingga diharapkan masyarakat memiliiki kebiasaan berdisiplin untuk hidup bersih. Pengumpulan sampah ini dikumpulkan setiap satu bulan, dua bulan, bahkan tiga bulan sekali untuk dapat di daur ulang dan 
akan dihitung lalu digantikan dengan sejumlah nominal mulai dari $\mathrm{Rp} 5.000,00$ atau tergantung dari berat sampah yang dikumpulkan.

Adanya interaksi sosial, baik yang sifatnya formal (dalam forum khusus) maupun informal, membuat ikatan sosial menjadi semakin erat dan mampu memunculkan rasa memiliki (sense of belonging) antar sesama warga maupun warga dengan lingkungan tempat tinggalnya. Selain itu, juga menambah nilai kenyamanan untuk bertempat tinggal. Hal ini yanng menjadi satu kelebihan yang menonjol dan menjadi ciri lain dari RW 7 Turusan.

Kebertahanan masyarakat di RW 7 Turusan terbentuk karena adanya hubungan antar individu yang masih terjaga dengan erat kaitannya dalam kehidupan bertetangga dan bermasyarakat. Selain itu, juga karena faktor lama tinggal yang lebih dari 30 tahun. Nilai kenyamanan tinggal di lingkungan RW 7 Turusan juga menjadi daya tarik tersendiri bagi warga asli dan pendatang untuk tetap bertahan tinggal dengan cara beradaptasi dengan lingkungannya yang kumuh. Upaya adaptasi ini digambarkan dengan adanya usaha dari berbagai lapisan, terutama dari masyarakat setempat untuk melakukan upaya-upaya perbaikan dan peningkatan kualitas lingkungan. Hal ini dapat direfleksikan dengan adanya kegiatan bank sampah dan koperasi sampah yang ternyata mampu memberi dampak ekonomi tersendiri bagi masyarakat, di samping manfaat bagi lingkungan.

Kondisi perekonomian yang ada di RW 7 Turusan dilengkapi seperti adanya pasar, toko maupun ruko-ruko modern dan pusat perbelanjaan (mall). Keberadaan sarana pendidikan yang ada di RW 7 Turusan tidak terlepas dari adanya sekolahsekolah pada umumnya mulai dari tingkat dasar, menenggah, hingga atas dan terdapat pula beberapa universitas maupun lembaga setingkat yang menjadi salah satu keuntungan tersendiri bagi masyarakat sekitar khususnya di Kelurahan Salatiga, karena dari adanya sarana pendidikan tersebut mampu mendongkrak perekonomian masyarakatnya. Kondisi ini tidak membuat sebagian besar aktivitas masyarakatnya menjadi berdaya karena kondisi ekonomi yang ada di RW 7 Turusan masih dalam kategori menengah kebawah. Gambar 6 menjelaskan bagan keterkaitan masing-masing faktor kebertahanan masyarakat di RW 7 Turusan ditinjau dari aspek sosial ekonomi.

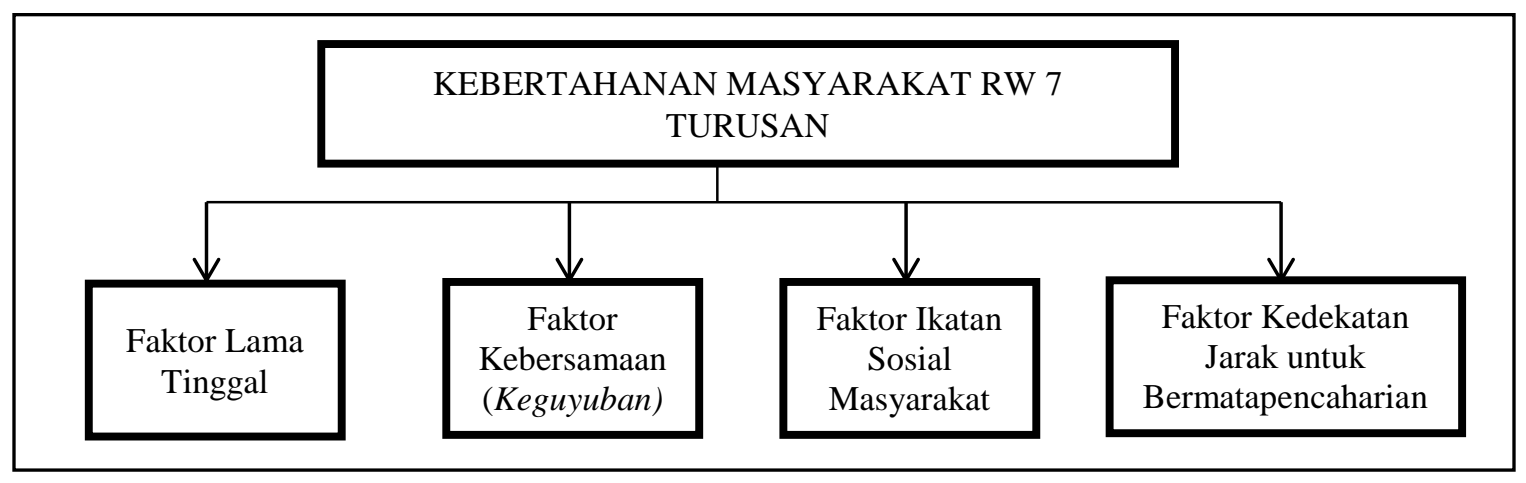

Gambar 6. Faktor Kebertahanan Masyarakat RW 7 Turusan Berdasarkan Aspek Sosial Ekonomi

Sebagaimana dijelaskan oleh beberapa penelitian sebelumnya, bahwa faktor lama tinggal dapat mempengaruhi kehidupan sosial dalam sebuah permukiman (Azahro \& Yuliastuti, 2013; Surtiani, 2006; Susanti et al., 2019). Sebuah permukiman yang didominasi oleh warga asli, meskipun secara keruangan keberadaannya dikelilingi bangunan komersial dan memiliki permasalahan internal permukiman, warga akan tetap memilih bertahan karena biasanya rumah tinggalnya sudah dihuni secara turun temurun. Lebih lanjut, dapat dikatakan bahwa kebertahanan ini dapat terjadi karena masyarakat telah memiliki keterikatan pada tempat tinggalnya sebagai ruang aktivitas ekonomi dan aktivitas sosial sehari-hari yang menjadikannya lingkungan nyaman untuk ditinggali. Dari kasus di RW 7 Turusan, kedekatan jarak permukiman dengan pusat kota menjadi daya tarik tersendiri bagi masyarakat untuk bertahan tinggal.

Ikatan sosial yang erat juga menjadi alasan tersendiri bagi warga untuk tetap tinggal. Adanya modal sosial di masyarakat menjadikan masyarakat memiliki peluang untuk bertahan meskipun dihadapkan pada berbagai permasalahan. Ikatan sosial dapat membangun inisiasi lokal di masyarakat untuk mengadakan program perbaikan lingkungan guna menciptakan lingkungan tempat tinggal yang lebih baik dan nyaman. Seperti temuan Andavarapu \& Arefi (2016), Dewi \& Syahbana (2015), dan Shirleyana \& Sunindijo (2018) bahwa adanya ikatan sosial yang direfleksikan dalam berbagai aktivitas sosial masyarakat, baik formal dan informal mempengaruhi kebertahanan penduduk pada permukiman kumuh. 


\section{KESIMPULAN}

RW 7 Turusan mengalami dinamika dalam kehidupan permukimannya. Kondisi fisik/topografi lingkungan dan kebiasaan masyarakat menjadi penyebab munculnya citra kumuh di RW 7 Turusan. Namun demikian, keberadaan RW 7 yang dekat dengan pusat Kota Salatiga, faktor ekonomi masyarakat bermata pencaharian di sekitar permukiman, faktor lama tinggal, faktor ikatan sosial yang erat menjadikan masyarakat memilih untuk bertahan atau tetap tinggal, dan faktor kebersamaan/ keguyuban masyarakat. Faktor lama tinggal menjadi faktor paling utama karena status kepemilikan rumah yang sudah milik sendiri dan telah didiami dalam jangka waktu lama/turun temurun. Masyarakat telah berupaya untuk melakukan upaya adaptasi dengan lingkungannya untuk mengurangi citra kumuh kawasan, seperti dengan kegiatan sosial yang berfokus pada lingkungan. Selain untuk memperbaiki kondisi lingkungan, kegiatan berwawasan lingkungan, seperti bank sampah juga berdampak pada ekonomi dan kondisi sosial masyarakat.

\section{DAFTAR PUSTAKA}

Ahmed, I. (2016). Building Resilience of Urban Slums in Dhaka, Bangladesh. Procedia - Social and Behavioral Sciences, 218, $202-213$. DOI: $10.1016 / j . s b s p r o .2016 .04 .023$

Andavarapu, D., \& Arefi, M. (2015). Resilient Slums: Role of Social Capital. Tekton, 2(1), 38-54. Diakses dari https://tekton.mes.ac.in/issues/volume-2-issue-1/papers-essays/resilient-slums-role-of-social-capital/

Andavarapu, D., \& Arefi, M. (2016). Understanding Resilience in Urban Slums: Lessons From Pedda-Jalaripeta, India. PlaNext, 02, 109128. DOI: $10.17418 /$ planext.2016.7vol.02

Aprianto, R. (2016). Proses Kebertahanan Kampung Petempen Dalam Perkembangan Kota. Jurnal Pembangunan Wilayah \& Kota, 12(3), 347-358. DOI: 10.14710/pwk.v12i3.12909

A.R.S. (2020, Maret 5). Komunikasi Personal

A.S.Y. (2020, Maret 4). Komunikasi Personal

Azahro, M., \& Yuliastuti, N. (2013). Kajian Kehidupan Masyarakat Kampung Lama Sebagai Potensi Keberlanjutan Lingkungan Permukiman Kelurahan Gabahan Semarang. Teknik PWK, 2(3), 481-490. Diakses dari https://ejournal3.undip.ac.id/index.php/pwk/article/view/2881

Badan Pengembangan dan Pembinaan Bahasa, Kementerian Pendidikan dan Kebudayaan Republik Indonesia. (2016). KBBI Daring. Diakses dari https://kbbi.kemdikbud.go.id/entri/BERTAHAN

Badan Pusat Statistika Indonesia. (2018). Persentase Rumah Tangga Kumuh Perkotaan (40\% ke Bawah), Menurut Provinsi 2015-2018. Diakses dari https://www.bps.go.id/dynamictable/2019/10/04/1667/persentase-rumah-tangga-kumuh-perkotaan-40-ke-bawahmenurut-provinsi-2015-2018.html

Chimankar, D. A. (2016). Urbanization and Condition of Urban Slums in India. Indonesian Journal of Geography, 48(1), 28-36. DOI: 10.22146/ijg.12466

Creswell, J. W. (2014). Research Design: Qualitative, Quantitative, and Mix Methods Approaches (4th ed.). Sage Publications.

Danso-wiredu, E. Y., \& Midheme, E. (2017). Slum upgrading in developing countries: lessons from Ghana and Kenya. Ghana Journal of Geography, 9(1), 88-108. Diakses dari https://www.ajol.info/index.php/gjg/article/view/154657

Dewi, D. P., \& Syahbana, J. A. (2015). Kebertahanan Kawasan Perkampungan Pedamaran Semarang. Teknik PWK, 4(1), 93-106. Diakses dari https://ejournal3.undip.ac.id/index.php/pwk/article/view/7737

D.S.R. (2020, Maret 5). Komunikasi Personal

Evansyah, E., \& Dewi, S. P. (2014). Kebertahanan Kampung Tua Sekayu Terkait Keberadaan Mal Paragon di Kota Semarang. Jurnal Ruang, 2(1), 301-310. Diakses dari https://ejournal3.undip.ac.id/index.php/ruang/article/view/3988

H.S. (2020, Februari 19). Komunikasi Personal

Indriani, I. (2017). Formasi Spasial Permukiman Kumuh Kota Studi Kasus: Perubahan Pola Ruang Bermukim pada Lahan di Jalan Sersan Sani Palembang. Jurnal Arsir, 1(1), 30-37. DOI: 10.32502/arsir.v1i1.855

Jones, P. (2017). Housing Resilience and the Informal City. Journal of Regional and City Planning, 28(2), 129-139. DOI: 10.5614/jrcp.2017.28.2.4

Juwono, S. (2009). Kampung Kuningan di Kawasan Mega Kuningan Jakarta Kebertahanan Kampung dalam Perkembangan Kota. Tesis, Universitas Diponegoro. Diakses dari http://eprints.undip.ac.id/55811/1/BAB_1.pdf

Krisandriyana, M., Astuti, W., \& Fitria Rini, E. (2019). Faktor yang Mempengaruhi Keberadaan Kawasan Permukiman Kumuh di Surakarta. Jurnal Desa-Kota, 1(1), 24-33. DOI: 10.20961/desa-kota.v111.14418.24-33

Magis, K. (2010). Community Resilience: An Indicator of Social Sustainability. Society \& Natural Resources, 23(5), 401-416. DOI: $10.1080 / 08941920903305674$ 
Mahabir, R., Crooks, A., Croitoru, A., \& Agouris, P. (2016). The study of slums as social and physical constructs: Challenges and emerging research opportunities. Regional Studies, Regional Science, 3(1), 399-419. DOI: 10.1080/21681376.2016.1229130

Miles, M. B., \& Huberman, M. (1994). Qualitative Data Analysis: An Expanded Sourcebook (2nd ed.). Sage Publications.

M.M.I. (2020, Februari 12). Komunikasi Personal

Nursyahbani, R., \& Pigawati, B. (2015). Kajian Karakteristik Kawasan Pemukiman Kumuh di Kampung Kota (Studi Kasus: Kampung Gandekan Semarang). Teknik PWK, 4(2), 267-281. Diakses dari https://ejournal3.undip.ac.id/index.php/pwk/article/view/8463\#: :text=Hasil\%20analisis\%20dari\%20kajian\%20terhadap,yang\%20se bagian\%20besar\%20memiliki\%20tingkat

Owusu, G., Agyei-Mensah, S., \& Lund, R. (2008). Slums of hope and slums of despair: Mobility and livelihoods in Nima, Accra. Norsk Geografisk Tidsskrift, 62(3), 180-190. DOI: 10.1080/00291950802335798

Peraturan Menteri Pekerjaan Umum dan Perumahan Rakyat Republik Indonesia Nomor 02/PRT/M2016 tentang Peningkatan Kualitas terhadap Perumahan Kumuh dan Permukiman Kumuh. Diakses dari https://peraturan.bpk.go.id/Home/Details/104644/permen-puprno-02prtm2016-tahun-

2016\#: :text=Permen\%20PUPR\%20No.\%2002\%2FPRT,Permukiman\%20Kumuh\%20\%5BJDIH\%20BPK\%20RI\%5D

Reivich, K., \& Shatte, A. (2002). The Resilience Factor: 7 Essential Skills for Overcoming Life's Inevitable Obstacles. Broadway Books.

S.G.O. (2020, Februari 17). Komunikasi Personal

S.G.Y. (2020, Februari 18). Komunikasi Personal

Shirleyana, S. H., \& Sunindijo, R. Y. (2018). City of Kampung: Risk and Resilience in the Urban Communities of Surabaya, Indonesia. International Journal of Building Pathology and Adaptation, 36(5), 543-568. DOI: 10.1108/IJBPA-02-2018-0025

S.K.A. (2020, Februari 11). Komunikasi Personal

Surat Keputusan Walikota Salatiga Nomor 658/440/2016 tentang lokasi program Kota Tanpa Kumuh (KOTAKU) di Kota Salatiga

Surtiani, E. E. (2006). Faktor-Faktor yang Mempengaruhi Terciptanya Kawasan Permukiman Kumuh di Kawasan Pusat Kota (Studi Kasus: Kawasan Pancuran, Salatiga). Tesis, Universitas Diponegoro. Diakses dari http://eprints.undip.ac.id/15530/\#: :text=Dari\%20hasil\%20analisis\%20studi\%20dapat,kepemilikan\%20hunian\%2C\%20dan\%20lam a\%20tinggal.

Susanti, A. D., Harani, A. R., \& Hasan, M. I. (2019). Faktor-Faktor Kebertahanan Kampung Malang, Semarang. Jurnal Arsir, 2(2), 65-70. DOI: 10.32502 /arsir.v2i2.1303

Tauhid, F. A. (2019). Developing Framework for Improving Disaster Resilience. Nature: National Academic Journal of Architecture, 6(1), 97-102. DOI: 10.24252/nature.v6i1a9

Uddin, N. (2018). Assessing urban sustainability of slum settlements in Bangladesh: Evidence from Chittagong city. Journal of Urban Management, 7(1), 32-42. DOI: 10.1016/j.jum.2018.03.002

UN-Habitat. (2003). The Challenge of Slums: Global Report on Human Settlements 2003. Diakses dari https://unhabitat.org/the-challengeof-slums-global-report-on-human-settlements-2003

UN-Habitat \& UNESCAP. (2008). Perumahan Bagi Kaum Miskin di Kota-kota Asia. Diakses dari https://www.unescap.org/sites/default/files/PERUMAHAN-BAGI-KAUM-MISKIN_PEMBIAYAAN-PERUMAHAN.pdf

UN-Habitat. (2007). What are Slums and why do they Exist? https://www.preventionweb.net/files/1700_462551419GC202120What20are20slums.pdf

Undang-Undang Republik Indonesia Nomor 1 Tahun 2011 tentang Perumahan dan Kawasan Permukiman. Diakses dari https://www.bphn.go.id/data/documents/11uu001.pdf

Walker, B., Folke, C., Carpenter, S.R., Scheffer, M., Chapin, T., \& Rockström, J. (2010). Resilience thinking: integrating resilience, adaptability and transformability. Ecology and Society, 15(4): 20. Diakses dari http:// www.ecologyandsociety.org/vol15/iss4/art20/) 